\title{
Young Adult Failure to Thrive Syndrome
}

\author{
WARREN C. SANDERSON, World Population Program at IIASA and \\ Economics Department, Stony Brook University, New York \\ VEGARD SKIRBEKK, World Population Program at IIASA and Centre on \\ Lifelong Lerning and Institutional Development, Jacobs University, Bremen \\ MARCIN STONAWSKI, World Population Program at IIASA and Department \\ of Demography, Cracow University of Economics
}

\begin{abstract}
Many young working age adults in developed countries are failing to thrive in economic, demographic and social terms. Their failure to thrive is a relatively new phenomenon that has not been widely recognized, but it affects young adults in virtually all the more developed countries for which we have relevant data. Young adults nowadays are more often in poverty. They are leaving their parental homes at ever later ages and in some countries the frequency of psychological problems increased. The seriousness of failure to thrive syndrome is reflected in the relationship between relative economic conditions and increased suicide rates. The syndrome is important because young adults are at the prime ages for finding employment, establishing long-run career paths and building an economic basis for founding a family. Developing strategies to arrest the spread of failure to thrive syndrome among young adults, in order to keep them vibrant contributors to our societies, should be a priority for policy makers.
\end{abstract}

Key words: young adults, poverty, career development

\section{Introduction}

The period of transition from one's family of origin to independent adult life is a crucial one. This is the stage at which young adults make decisions about schooling, housing, careers, conjugal partnerships and childbearing - decisions that will have a long-term effect on their wellbeing and through demographic change the fiscal sustainability of national economies. If they fail to thrive at this critical phase of their life cycle, their ability to develop to their fullest potential in later adult life could be reduced.

In some countries this syndrome has already been recognized. In Italy, the novel "Generazione mille euro" gave a name to a generation and spawned a movie and a popular website (New York Times 2006; Incorvaia and Rimassa 2006; www.Generazione1000. com). The 1,000 Euro generation is composed of young people, many of whom are quite educated, who live on low and insecure incomes and who have difficulty in finding a long-term stable job. In France, this generation is known as "Génération précaire" (Newsweek 2007). In Spain, the members of this generation are called "mileuristas" 
(Guardian 2008). In Germany, these young people belong to "Generation Praktikum" (Hommerich 2009). In Japan, they are known as "freeters" (Hommerich 2009). All over the developed world, young adults are failing to thrive.

In each country, there are specific explanations of why the young are having such difficulties. We show here that these local explanations of young adult failure to thrive syndrome miss an essential point. The syndrome is a worldwide phenomenon. Although national characteristics certainly play a role in modifying its extent, they cannot explain its widespread appearance. Explanations of the syndrome also often focus on the most recent causes. Currently, these revolve around the fiscal difficulties of state finance. However, the origins of the syndrome are evident at least from the 1980s onward. Concentrating only on its most recent manifestations can cause a misdiagnosis.

Before we delve into the data, however, it is useful to think for a moment about the sorts of causes which could affect the well-being of the young in so many places over the last three or more decades. We divide the potential causes into those that affect the supply side of the labor market and those that affect the demand side.

We believe three factors were important on the demand side: (1) the massive increase in the globalized labor force, (2) the education revolution, and (3) the increase in women's labor force participation. From the 1970s onward many countries that had been relatively closed to international trade liberalized their economies, implementing easier regulations for imports and exports, allowing freer movement of international capital, and allowing the repatriation of profits. We made two lists including countries with labor forces of 19 million or more in 2012. The first list was of the more developed countries that accounted for the bulk of international trade in 1970. These were the countries in the current European Union, the United States, Japan, and Canada. In the other list there were many of the countries whose labor forces were added to the globalized total after 1970. These included China, India, Indonesia, Brazil, Bangladesh, Russia, Pakistan, Mexico, Vietnam, Philippines, Thailand, and the Republic of Korea. In 2012, the combined labor force of the more developed economies accounted for only 20 percent of the total labor force on the two lists. Between 1970 and now, the labor force actively engaged in international trade massively exploded, with the labor forces of the countries in the second list rising from a very low level to around 80 percent of the global total. Easy capital mobility and an exploding pool of potential workers made the reallocation of capital to places where it was relatively scarce both profitable and a virtual competitive necessity. The speed and magnitude of this global change was unprecedented in recent economic history and it would have quite strange if it did not have widespread and long-lasting consequences. The growth of the globalized labor force is now slowing. China's labor force is on the verge of shrinking and lower birth rates in past suggest that there will be lower labor force growth rates in the future in many other developing countries. 
Not only has the globalized labor force exploded, but there has been and continues to be an education revolution in the countries that have newly become more active in international trade. For example, in 1970, China had about 68 million people 20-64 years old with some secondary education or more. India had around 34 million, for a total of 102 million people. The US, in 1970, had around 92 million people with some secondary education or more, slightly less than the total of China and India. According to forecasts for 2015, China and India's populations of 20-64 year olds would have increased around 10-fold, to 673 million for China and 353 million for India. In the same time period, the population in the United States with that level of education would have roughly doubled to 184 million. In 1970, China and India together had about 11 percent more people 20-64 with some secondary education or more than the US. By 2015, they would have around 460 percent more. The education revolution happened in all the developing countries that became more engaged in international trade after 1970. Not only was there a massive increase in the globalized labor force but there was, in addition, an upward leap in the educational attainments of those people most responsible for increasing it. Naturally, rapidly-growing, relatively low wage labor with high skill levels would prove attractive for those with capital.

The third factor on the supply side was the increase in women's labor force participation. This was driven by a number of changes, including the decline in the number of children women had, increases in their level of education, improvements in the technology of housework resulting from more efficient household appliances and a steep decline in their relative prices, and eventually a decline or stagnation in their partners' incomes.

Changes on the demand side have been far less dramatic. Technological changes have created and destroyed jobs. The long-term trend has been toward the production of relatively more jobs in the service sector and relatively fewer in the industrial sector. This trend has been reinforced by the explosion of the labor force actively engaged in international trade, because that increase lowered the prices of tradable goods, which, for the most part, were the product of the industrial sector. Service sector jobs were more likely to be in sectors, such as teaching, where international competition had less effect. The relative increase in service sector jobs was accommodated to a significant degree by the increase in the labor force participation of women. The relative decrease in industrial jobs had its largest effect on men, particular young men.

The final demand side change is the most recent one, the exigencies of state finance. The governments of some developed countries have experienced large increases in their deficits due to a combination of supporting their banks and stimulating their economies in the face of a dramatic economic downturn. As a result, strong efforts are being made to reduce government expenditures, which have an immediate consequence of reducing output and employment. The problems of state finance, interact with the longer term trends, making the problems of employment even more difficult. 
The massive changes in the labor market required countries to adjust. The nature of the adjustments differed by country, but they generally had a common element. The brunt of them was borne by the people who could protect themselves the least, particularly the young. The result is a widespread and deepening failure to thrive syndrome. This syndrome robs a country's future, by stunting the development of its young adults.

The object of this article is to document young adult failure to thrive syndrome as a distinct socio-economic phenomenon of long duration and broad geographic applicability. We provide evidence for the failure to thrive syndrome, beginning in the next section by discussing the decline in the relative economic conditions of young adults. As seen in the ensuing section, this deterioration is reflected in increases in their suicide rates. The fourth section explains how life satisfaction, marriage, divorce, fertility, and health are all affected by changes in relative economic conditions. The fifth section discusses the relative decline in female subjective wellbeing and shows that it is consistent with the failure to thrive syndrome. The final section contains our concluding thoughts. The article is a revised and expanded version of a IIASA report (Sanderson, Skirbekk and Stonawski 2011).

\section{Declining Relative Economic Conditions}

Young adulthood is best not defined as a period between two predetermined chronological ages. It is better to conceptualize it functionally as the period in which people complete their education, establish a career path, find a stable job, identify a partner, establish a stable union and become a parent. There is no single correct measure of relative income of these young adults because there are a number of ways of measuring income and a variety of standards against which to compare it. Therefore, in this section, we look at relative incomes from a number of viewpoints and show that young adult failure to thrive syndrome shows up in all our measures.

Young adult failure to thrive syndrome is a general phenomenon in developed countries. One way to see this is to consider the relative poverty of young adults. The OECD has computed the relative poverty rates by age for subsets of its countries (OECD 2008). For the average of seven countries (OECD-7), data are available for the mid-1970s, the mid-1980s, the mid-1990s, around 2000, and the mid-2000s. For the average of 23 countries (OECD-23) information is available only from the mid-1980s onward. Figure 1 shows the data for 26 to 40 -year-olds and for 51-65-year-olds. Relative poverty is defined as an individual having a cash income less than 50 percent of the median cash income in the person's country. 


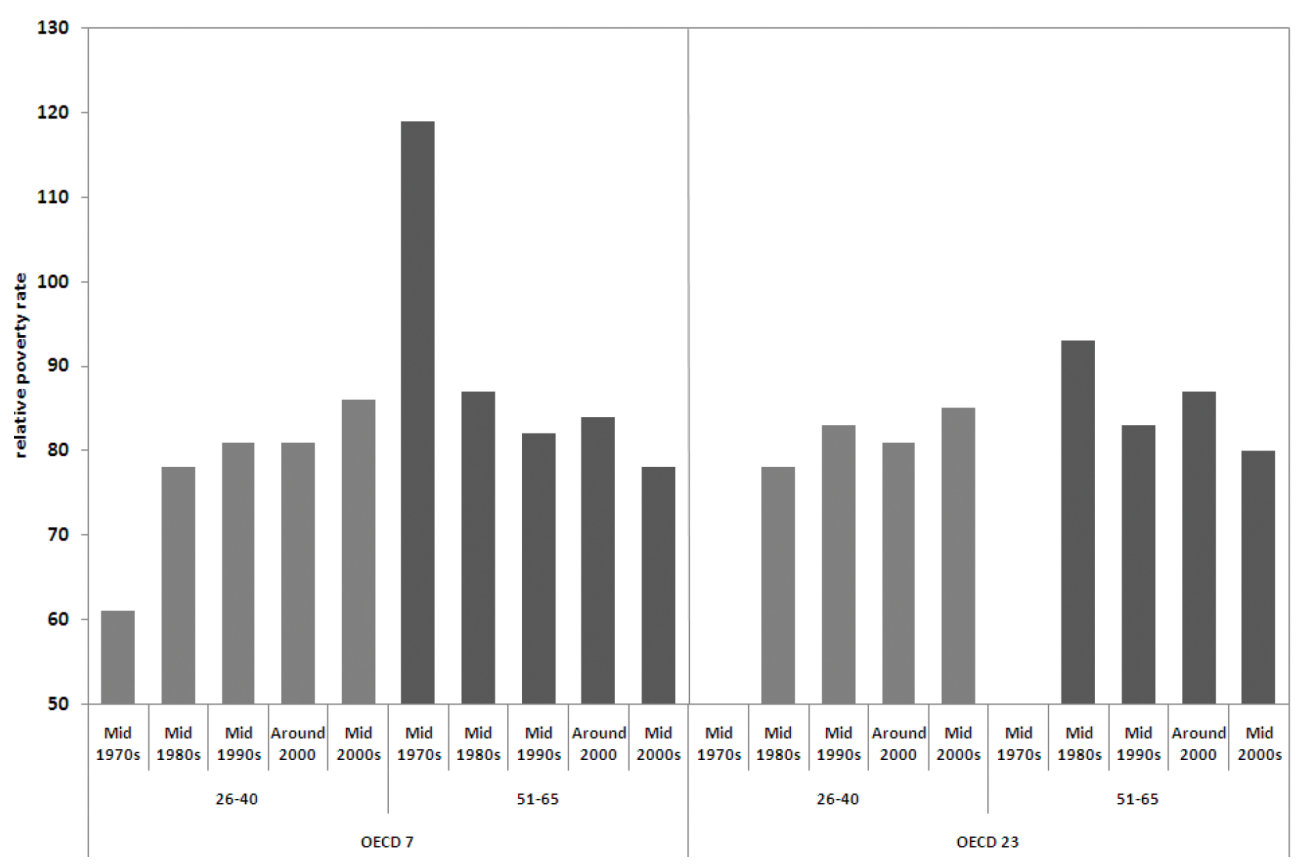

Figure 1. Relative poverty rates in selected OECD countries from the mid-1970s to the mid-2000s. Source: OECD (2008: 132) and http://dx.doi.org/10.1787/422163541278. Note: 100 = poverty rate for the country in the indicated period.

Relative poverty rates are ratios of age-specific poverty rates to national ones. People in poverty have incomes below 50 percent of the national median income.

OECD 7 includes average of Canada, Finland, Greece, the Netherlands, Sweden, the United Kingdom, and the United States.

OECD 23 includes average of all OECD countries except Australia, Belgium, Iceland, the Republic of Korea, Poland, the Slovak Republic, and Switzerland.

In the mid-1970s, the relative poverty rate for the OECD-7 was 61 (national poverty rate $=100$ ) for the 26-40 year olds and almost double for the 51-65-year-olds. By the mid-2000s the relative poverty rate for the 26-40-year-olds had risen to 86 , while for the 51-65-year-olds it had fallen to 78 . The relative poverty rate fell dramatically for the 51-65-year-old population, while it rose considerably for the younger people. The pattern that we see in Figure 1, a rise in the data for the younger adults from the mid-1970s through the mid-1990s, a leveling off, and then a continued rise in the early years of the 2000s, will be broadly replicated in other measures of relative income. The picture from the OECD-23 is basically the same. In the mid-1980s, there was more relative poverty among the 51 to 65 year olds than among the 26 to 40 year olds. By the mid-2000s, the situation was reversed (OECD 2008).

The OECD findings on worsening relative conditions for the young are consistent with other findings. For example, in the US, poverty in the 1960s was higher among the 
$65+$ than among the youth, but this reversed in the 1970s. By 2007 youth poverty rate was 18.0 percent, while poverty rates among the 18-64-year-olds was 10.9 percent (US Census Bureau 2008). It is also consistent with evidence from Statistics Sweden, which shows that between 1980 and 2003, the share of Swedish 20-24-year-olds who reported having health problems increased from 7 percent to 10 percent, while for the 60-64-year-olds the share decreased from 41 percent to 36 percent. Individuals in their 20s were less likely to have access to cars in 2003 than in 1980, and available living space decreased for the young. Between 1980 and 2003, the number of individuals per 100 rooms increased from 59 to 65 for 20-24-year-olds, while it decreased from 41 to 34 for the 60-64-year-olds (Vogel and Råbäck 2004).

Young adult failure to thrive syndrome has developed differently for the two sexes, so it is useful to show what has happened to their relative incomes separately. Table 1 shows changes in percentages of 26-30-year-old men and women in Belgium, West Germany, Italy, the UK, Canada, and the US, who have incomes above 50 percent of the national median adjusted income. The data cover roughly a period of a decade and a half from the mid-1980s to around the turn of the century. All figures are adjusted for family size by dividing incomes by the square root of the number of people in the household.

Table 1. Percent point change in the number of 26-30-year-olds who have the indicated variable above 50 percent of the national median adjusted disposable income, 1994-2000. Source: Bell et al. (2007: Tables 6 and 8). Original data: LIS (2010).

\begin{tabular}{lccccc}
\hline Country & $\begin{array}{c}\text { Starting-ending } \\
\text { date }\end{array}$ & \multicolumn{2}{c}{$\begin{array}{c}\text { Individual income adjusted } \\
\text { for family size }\end{array}$} & \multicolumn{2}{c}{$\begin{array}{c}\text { Average family income } \\
\text { adjusted for family size }\end{array}$} \\
\hline \multirow{3}{*}{ Belgium } & $1985-1997$ & -13 & 5 & -8 & Females \\
W. Germany & $1984-2000$ & -10 & -3 & -4 & -4 \\
Italy & $1987-2000$ & -15 & 9 & -2 & -2 \\
UK & $1986-1995$ & -6 & 13 & -1 & -5 \\
Canada & $1987-1997$ & -5 & 3 & -3 & 0 \\
USA & $1986-2000$ & 1 & 6 & 0 & 0 \\
\hline
\end{tabular}

The left two columns of Table 1 show the percentage point change based on individual wage and salary incomes. In five out of six countries, the change was positive for women and negative for men. Taken as individuals, women's relative incomes improved over the period covered in the table and men's relative incomes deteriorated. These are well known findings and on their face they appear to indicate that only young men were failing to thrive.

The right two columns indicate what happened to the incomes of the families in which the young men and women were living. The percentage point change in the percentage of 26-30-year-old men who lived in families with adjusted personal incomes above 50 percent of the national median adjusted personal income was negative in five out 
of the six countries and zero in the US. For females, we see decreases in four out of the six countries and no change in the other two. When we consider men and women in family units, rather than as individuals, we see that both experienced declines in their joint economic resources even taking household economies of scale into account. The deterioration in the economic conditions of young men more than outweighed the improvement for young women.

In Table 2 (see next page), we focus on the relative economic conditions of young men in 14 developed countries and in Taiwan. We present ratios of the median earnings of 25-34-year-old men to the median earnings of 45-54-year-old men. The medians are computed only over those with earnings. We have gathered data from surveys in the 1980 s, 1990s, and early 2000s. In 13 of the observations the ratio of median earnings of the younger to older men decreased from the 1980s to the early 2000 s, indicating a long-run deterioration in the relative economic condition of young men. This deterioration was not monotonic. In a number of places, there was some improvement in the relative economic conditions of young men from the 1990s to the early 2000s.

Another approach to conceptualizing and measuring relative income of young adults is to view it relative to the incomes of families in which they grew up. Macunovich (1998) provides data on the average earnings of young men in their first five years of work experience relative to the income of families with heads aged 45-54 years five years earlier. For both Whites and African-Americans, relative incomes fell from 1970 to the mid-1980s, rose a bit to 1990 and then fall again to the mid-1990s. In Figure 1 above, we saw some deterioration in the relative income of the young from the beginning of the 2000s to the middle of the decade. Further, the current climate of economic weakness in many developed countries seems likely to exacerbate the decline in the relative incomes of the young. In the US, the employment population ratio for men 25 to 29 was 89.3 percent in April of 2000 and fell by 11.4 percentage points to 77.9 percent in April 2010. The employment population ratio for 50 to 54 year old men started out at 85.2 percent in April 2000, which is lower than the rate for the younger men. By April 2010, the rate had fallen only 6.5 percentage points to 78.7 percent and was then higher than the rate for the younger men. 
Table 2. Median real gross or net earnings for 25-34 and 45-54-year-old men and their ratio from the 1980s through the early 2000s. Sources: LIS (2010); OECD (2007).

\begin{tabular}{|c|c|c|c|c|}
\hline \multirow[t]{2}{*}{ Country } & \multirow[t]{2}{*}{ Year } & \multicolumn{2}{|c|}{ Earnings } & \multirow[t]{2}{*}{ Wage Ratio } \\
\hline & & $25-34$ & $45-54$ & \\
\hline \multirow[t]{3}{*}{ Australia } & 1980s & 100 & 100 & 99 \\
\hline & 1990s & 100 & 109 & 87 \\
\hline & early 2000 s & 111 & 126 & 91 \\
\hline \multirow[t]{3}{*}{ Belgium* } & 1980s & 100 & 100 & 85 \\
\hline & 1990s & 107 & 113 & 80 \\
\hline & early 2000 s & 122 & 127 & 82 \\
\hline \multirow[t]{3}{*}{ Canada } & 1980s & 100 & 100 & 83 \\
\hline & 1990s & 86 & 100 & 72 \\
\hline & early 2000 s & 90 & 101 & 74 \\
\hline \multirow[t]{3}{*}{ Denmark } & $1980 s$ & 100 & 100 & 93 \\
\hline & 1990s & 96 & 103 & 87 \\
\hline & early 2000 s & 100 & 108 & 87 \\
\hline \multirow[t]{3}{*}{ Finland } & 1980s & 100 & 100 & 86 \\
\hline & 1990s & 102 & 107 & 83 \\
\hline & early 2000 s & 124 & 120 & 89 \\
\hline \multirow[t]{3}{*}{ France* $^{*}$} & 1980s & 100 & 100 & 85 \\
\hline & 1990s & 93 & 105 & 75 \\
\hline & early 2000 s & 92 & 103 & 75 \\
\hline \multirow[t]{3}{*}{ Italy* } & 1980s & 100 & 100 & 93 \\
\hline & 1990s & 93 & 106 & 81 \\
\hline & early 2000 s & 92 & 106 & 80 \\
\hline \multirow[t]{3}{*}{ Luxembourg* } & 1980s & 100 & 100 & 87 \\
\hline & 1990s & 126 & 153 & 73 \\
\hline & early 2000 s & 140 & 180 & 68 \\
\hline \multirow[t]{3}{*}{ Netherlands } & 1980s & 100 & 100 & 85 \\
\hline & $1990 s$ & 104 & 113 & 78 \\
\hline & early 2000 s & 103 & 113 & 77 \\
\hline \multirow[t]{3}{*}{ Norway } & 1980s & 100 & 100 & 91 \\
\hline & 1990s & 97 & 104 & 85 \\
\hline & early 2000 s & 115 & 121 & 87 \\
\hline \multirow[t]{3}{*}{ Spain* } & $1980 s$ & 100 & 100 & 107 \\
\hline & 1990s & 85 & 117 & 78 \\
\hline & early 2000 s & 94 & 131 & 77 \\
\hline \multirow[t]{3}{*}{ Sweden } & 1980s & 100 & 100 & 86 \\
\hline & 1990s & 106 & 110 & 83 \\
\hline & early 2000 s & 131 & 131 & 86 \\
\hline \multirow[t]{3}{*}{ Taiwan } & 1980s & 100 & 100 & 100 \\
\hline & 1990s & 172 & 196 & 88 \\
\hline & early 2000 s & 180 & 212 & 85 \\
\hline \multirow[t]{3}{*}{ UK } & 1980s & 100 & 100 & 95 \\
\hline & 1990s & 116 & 120 & 87 \\
\hline & early 2000 s & 129 & 136 & 85 \\
\hline \multirow[t]{3}{*}{ US } & 1980s & 100 & 100 & 77 \\
\hline & 1990s & 83 & 97 & 66 \\
\hline & early 2000 s & 88 & 98 & 70 \\
\hline
\end{tabular}

Notes: Average figures from surveys in the $1980 \mathrm{~s}=100$.

Wage ratio is defined as median wage for males aged 25-34 over median wage for males aged 45-54.

* countries for which net income was only available.

** data on gross income in Australia comes from OECD (2007). 
Economic downturns in the 1990s resulted in less hiring and staggering increases in unemployment among young men in particular (EU 2009). Evidence from the "Big 5 crises" - Spain, Sweden, Finland, Norway and Japan - shows that unemployment problems for men aged 15-24 may remain for years after the economy begins to grow again (Reinhart and Rogoff 2008; Verick 2009). For example, during the Swedish crisis around 1990, unemployment for men aged 25-54 rose from 1.1 percent to 9.3 percent, while unemployment among 15-24-year-old men rose from 3.9 percent to 26.1 percent. In Finland, where GDP collapsed by 14 percent from 1990 to 1993, unemployment grew from below 10 percent to a peak of 31.5 percent in 1994 for young Finnish men - twice the level experienced by the prime age group. Youth unemployment in Finland only slowly decreased. Even by 2008 youth unemployment had not reached the pre-crisis level, although GDP per capita surpassed its pre-crisis level in 1997 (Verick 2009).

Cross-sectional measures of the economic conditions of the young, informative as they are, miss an important element. Not only has the economic situation of young adults worsened on average, but their economic insecurity has also increased. Economic insecurity is difficult to quantify and presenting the details of studies that measure them is beyond the scope of this paper. Farber (2007) found increasing job insecurity in the US. Genda (2006) in his aptly titled book, A Nagging Sense of Job Insecurity: The New Reality Facing Japanese Youth, found it in Japan. Mills et al. (2005) found it in 14 countries: Germany, Netherlands, France, Sweden, Norway, Hungary, Estonia, Britain, Canada, the United States, Mexico, Italy, Spain, and Ireland. Studies with less age specificity for the US also show increases in income insecurity (Moffitt and Gottschalk 2002; Hacker 2008; Hacker et al. 2010).

Younger age groups have recently taken the brunt of welfare, pension and labor reforms. The "last in, first out" principle, advocated by many unions, worsens the employment stability of younger workers, while seniors are more sheltered from economic fluctuations (Oswald 1987). Decreasing incomes and increasing economic insecurity at younger ages are likely to have long term effects. Those who suffer relatively low wages at younger ages are likely to be "scarred" for life, implying that their risk of unemployment and their wage levels will be lower at higher ages than cohorts who experienced less difficult labor market conditions in their youth (Arulampalam et al. 2000; Gregg and Tominey 2005). Evidence from surveys reveals that key prerequisites for family formation and childbearing are a sufficiently high income, reasonable housing and even more importantly: stable employment with longer term prospects (Andersson 2000; Koytcheva and Philipov 2008; Kravdal 1999). The young may choose to postpone or not enter parenthood altogether if their income is too low. Age-earnings curves that peak late in life can make family formation difficult, and the slope of earnings curves are associated with postponed fertility (Van Bavel 2010). Not only have the relative incomes of young adults tended to decrease, so have their relative wealth (Jappelli and Pistaferri 2000; Haffner 2004; Klevmarken 2006). 
In this section, we have presented evidence from a wide variety of sources. They all tell a consistent story: The economic conditions in which young adults find themselves have gotten more difficult, affecting their ability to thrive.

\section{Suicide}

One of the most striking indicators of the young adult failure to thrive syndrome is the negative correlation between changes in the wage ratios for young adult men and changes in their suicide rates. This is shown in Figure 2. The data are for the three periods and cover the 14 countries in Table 2 . The correlation between changes in the wage ratios and suicide rates is -0.7 . Without the two outliers, Luxembourg $80 \mathrm{~s}-90 \mathrm{~s}$, and Spain $80 \mathrm{~s}-90 \mathrm{~s}$, the correlation is -0.57 . Both correlations are statistically significantly different from zero ( 95 percent confidence).

Suicide rates are sensitive to many forces not just young adult failure to thrive syndrome. Because of this, it would be misleading just to plot the levels of suicide rates against the wage ratio. To control better for other factors that are acting on suicide rates, we focus on the relationship between changes in suicide rates and changes in wage ratios. This provides a more robust test of their connection.

All the indicators of young adult failure to thrive syndrome are imperfect to some degree. This is also the case for suicide rates. We need to be cautious about how we treat the extent of decline from 1985-89 to 2000-04. It is possible that some of the decline in suicide rates in that period was due to the introduction of more effective medications for treating schizophrenia, depression, and bipolar disorder and to stronger anti-suicide programs that were put in place in the late 1980s and early 1990s because of substantial increases in suicide rates that had recently occurred.

The worsening economic conditions of young men alone do not, by themselves, provide strong evidence for the failure to thrive hypothesis. In theory, it is possible that the deteriorating relative economic conditions of the young men were, for the most part, something that was chosen by them. This argument starts from the idea that the young men wanted a period of prolonged experimentation in which they were "finding themselves." In this period of experimentation, it could be argued that the young desired the freedom to find a career path in a more leisurely manner. If this argument were true it would be hard to understand why having voluntarily chosen worse relative economic conditions, young men would have chosen to commit suicide more often. 


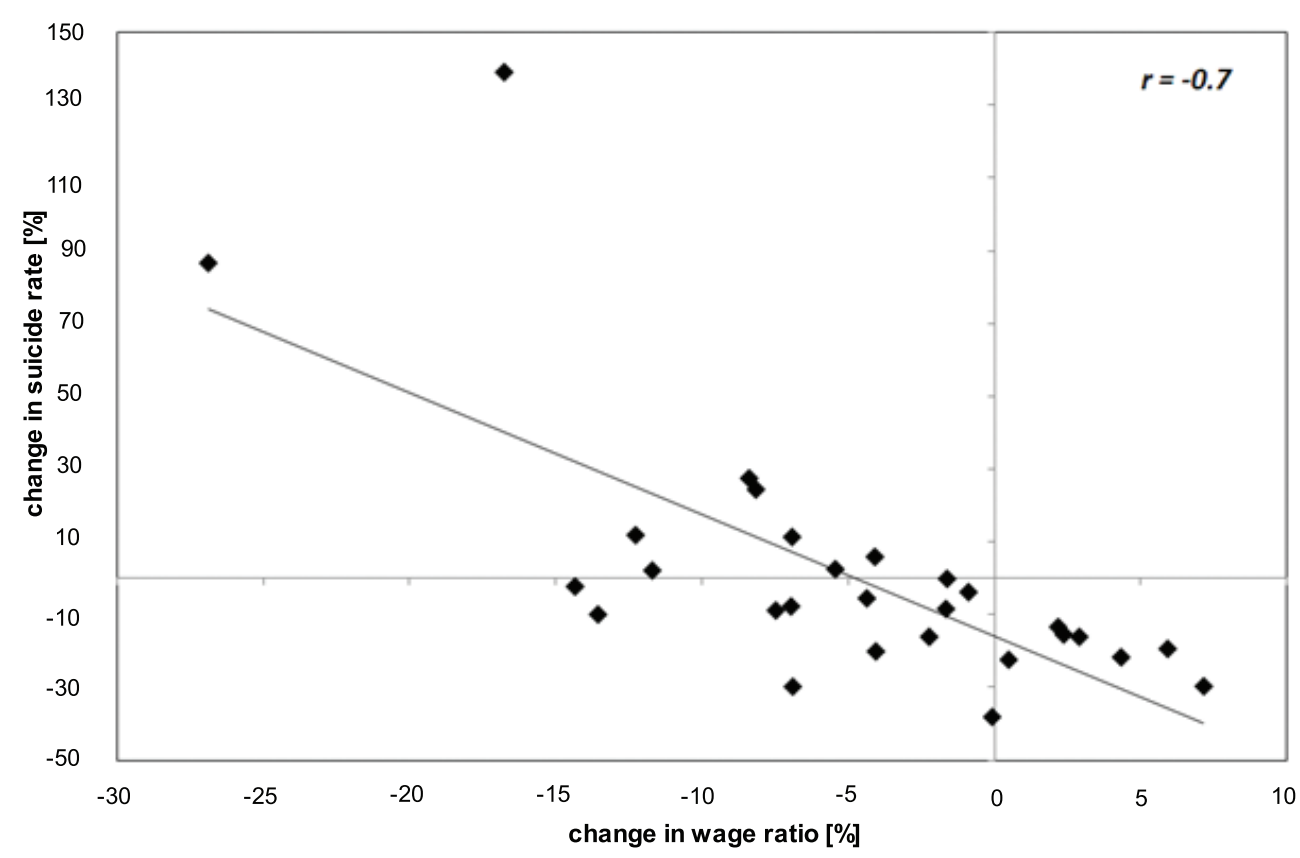

Figure 2. Relative changes in the wage ratio and relative changes in the suicide rate of men ages 25-34. Sources: Data on earnings: OECD (2007); LIS (2010). Data on suicide: WHO (2010).

Notes: Countries are Australia, Belgium, Canada, Denmark, Finland, France, Italy, Luxembourg, the Netherlands, Norway, Spain, Sweden, United Kingdom and United States.

Wage ratio is in Table 2.

Relative change in the wage ratio is $\frac{(\text { wage rate }(t+1))-(\text { wage rate }(t))}{(\text { wage rate }(t))}$

Relative change in the suicide rate is $\frac{(\text { suicide rate }(t+1))-(\text { suicide rate }(t))}{(\text { suicide rate }(t))}$

Correlation without the two outliers - Luxembourg 80s-90s; Spain 80s-90s - is -0.57 and is also statistically significant (at the 95 percent level - p-value $=0.0022$ ).

\section{Relative Incomes and Demographic Behavior}

In this section, we look at cross-sectional studies that relate relative incomes and demographic behavior. The role of relative income in affecting demographic variables was introduced by Easterlin (1966). In that paper, Easterlin tried to explain fertility changes in the US baby boom using a relative income measure defined as the ratio of the median income of families with heads 14-24-years-old to the median income 
five years earlier of families with heads $35-44$ years old. Since then there have been a large number of publications reformulating the details of how relative income is used in statistical analysis and applying the idea to a wide variety of demographic and nondemographic outcomes. More generally, relative wages have been found to be strongly related to an individual's well-being and to matter more than absolute income levels (Clark and Oswald 1996; Grund and Sliwka 2003).

Above, we showed that in a group of developed countries changes in the suicide rates of young men were negatively correlated over time with changes in their relative incomes. A recent cross-sectional study based on county-level data from the US (Daly et al. 2010) finds a robust correlation between relative incomes and suicide rates for adults 20-64. The incomes that were used are predicted family incomes based on the characteristics of individuals. They were measured relative to county-level family incomes. This cross-section confirmation of our time series results is important because in the time series results, we could not control for the effects of increased use of psychotropic medications. So even though the Daly et al. (2010) study does not focus on young men, its consistency with our time series results strengthens our confidence in them.

Among young adult males, generally those with lower incomes are less likely to be married than those with higher incomes. Watson and McLanahan (2009), using US data, find that the relative income of young men is an important determinant of whether or not they are married. Men with higher relative incomes were more likely to be married. This effect is consistent with the international data on headship rates in Bell et al. (2007: Table 1). Macunovich (2011a) takes a somewhat different approach, but her findings are also consistent with these.

Surveys from several industrialized countries suggest that women perceive their partner's income to be more important than their own wages when it comes to family formation. The Japanese National Survey on Work and Family (2007) shows that as a precondition for marrying for those aged 25-34, the partner's income level is "not very important" or "not important at all" for 69 percent of the men, but only among 5 percent of the women. Even in Norway, which had one of the world's highest female labor force participation rates (79 percent in 2008), a 2008 survey finds that 7 out of 10 women prefer that the man is the main breadwinner of the family (NRK 2008; OECD 2010). Liu and Vikat (2004) studied the effects of differences in the ratio of husband's to wife's earnings in Sweden. They found that the higher that ratio, the lower the probability of divorce.

Easterlin (1966) introduced the argument that relative income could be used to explain changes in US fertility over the baby boom. In that article, he showed that the ratio of the median income of families with heads 14-24 to the median income of families with heads 35-44 five years earlier was highly correlated with the fertility of the young. In subsequent articles, for example, Easterlin (1980) the measure of relative income changed, but the basic argument remained the same. A survey of the tests of 
the relationship between relative income measured in various ways and fertility (Macunovich 1998) found that most of the studies were consistent with Easterlin's view that the relative income of young men influenced fertility.

In a series of papers published in 2011, Macunovich (2011a, 2011b, 2011c) studies the effects of relative income on women's labor force behavior, the marriage rates of men and women and on fertility. Instead of defining a single relative income measure, she runs regressions that include, among other variables, the wage rates of men and lagged average family income in families with heads $45-54$ years old. In almost all cases, the coefficients on the men's wage rate and lagged average family income is consistent with the view that relative incomes are important determinants.

Relative income also affects mortality and morbidity. Eibner and Evans (2005) combine a number of US datasets to analyze the effects of what they call relative deprivation on both deaths and disease prevalence and health habits. They found that there is a positive and statistically significant association between their measure of relative deprivation and the person dying within the subsequent five years (p. 615). A register based study of 1.68 million men and women in Norway (Elstad et al. 2006) found that income relative to that in the surrounding residential area was negatively related to mortality risk for people with low absolute incomes living in places with 20,000 or more inhabitants. For people with high absolute income, there was no effect of relative income.

Changes in relative economic circumstances have many consequences, but they are not the main causes of many of them. For example, mortality and morbidity are affected by relative economic conditions and many other factors as well. Government policies can affect relative economic conditions and their resulting effects.

\section{Failure to Thrive Syndrome and the Subjective Wellbeing of Women}

Failure to thrive syndrome manifests itself differently among young men and young women. Indeed, it seems a bit odd to even raise the possibility of a failure to thrive syndrome among young women. The last decades seem to have been a golden age for them. Their labor force participation rates rose dramatically and in many developed countries are almost as high as for men. Wage rates for young women, although still below those of young men, have risen. The proportion of young women in colleges now exceeds the proportion of young men, and young women now make up an ever increasing share of young professionals. It is, therefore, quite paradoxical that measures of subjective well-being show that the happiness of women in the US has declined both absolutely and relative to that of men (Stevenson and Wolfers 2009). The decline in the happiness for women is substantial. It would be roughly equivalent to the welfare loss from the unemployment rate rising for 4.5 percent to 12.5 percent. In Europe, 
the happiness of women has tended to increase over time, but still fell relative to men (Stevenson and Wolfers 2009). Many factors affect how people respond to questions on happiness, including their level of education. As the level of education increased in Europe, we would generally expect rising scores on happiness as observed. In this perspectives, it is even more surprising that women's happiness fell relative to men's because their education level rose more rapidly.

Stevenson and Wolfers study relative happiness in a number of domains and find that none fully explains the decrease in the relative happiness of women. The financial domain, however, matters more than most. At the beginning of the US data, men and women were about equally satisfied with their household's financial position. By the end of the period, women were substantially less satisfied than men. It is also interesting that both men and women have become less happy with their marriages over time. Since the happiness of men and women with their marriages declined at about the same rate, this factor cannot account for the decrease in the relative happiness of women, but it could be a factor in decreasing proportions of young people married.

Young adult failure to thrive syndrome manifests itself differently for men and women. For men, their lower relative incomes and less secure job prospects have reduced their role as the prime breadwinner in families and reduced their value in the marriage market. For families, the lack of stable support by men has been compensated in part by the increased earnings of women. This is exactly what we saw in Table 1.

For women, the situation is different. Earlier they lived in families where their spouses had more stable and relatively better paying jobs. As opportunities for women expanded and the relative economic conditions of their spouses deteriorated, women began to contribute ever larger shares of family incomes. Thus, women were affected in two ways. First, the likelihood of stable family support from spouses diminished, and sec-

ond, they became more tied to an increasingly uncertain set of labor market conditions. Thus, while women buffered the deterioration in the relative economic conditions faced by men, they did this by becoming more vulnerable to those conditions themselves.

It is not the case that women are thriving and men are suffering. Young men and women typically live together. The declining economic circumstances of young families (as we showed in Table 1) prove that young adult failure to thrive syndrome affects both sexes.

\section{Discussion}

In describing young adult failure to thrive syndrome, we started by discussing the deteriorating economic conditions faced by young adults. This was motivated by the fact that young adult failure to thrive syndrome is an international phenomenon. It has similar characteristics in many countries. Therefore, no explanation based on the particular situation in a given country would be complete. Another factor argued in favor of this ordering as well. Relative incomes of young men worsened from the 
1980 s to the 1990s and then slightly improved in the early 2000s. We see a similar dynamic in the suicide rates of young people.

Thus it appears that deteriorating economic conditions played an important role in failure to thrive syndrome, but we are not arguing that it played the only role. Economic conditions, suicide rates, demographic changes, and the lengthening period of emerging adulthood are all interconnected in a complex web. Poor economic prospects of young men can lead to depression, which has a feedback effect on their economic performance and their ability to be a partner in a stable family. Young men with poor job prospects are more likely to be in unstable relationships, which affects their economic circumstances and their likelihood of committing suicide. Young men without partners are more likely to engage in criminal activity and risky behaviors. All young adults are not equally susceptible to the failure to thrive syndrome. It is most prevalent among those with the least education (Danziger and Ratner 2010). They are becoming ever more marginalized in today's developed countries.

But failure to thrive syndrome is hardly limited to those with the least education. In Canada, for example, Beaudry and Green (2000) find, using data from 1971 to 1993, that the age profiles of real earnings of successive cohorts of young men declined, both for men with a college education and those without one. In addition, from 2000 to 2011, the earnings of people with a university degree rose less rapidly than those with less education (Statistics Canada 2013). Education is certainly beneficial in helping to avoid young adult failure to thrive syndrome, but it does not make people immune to it.

A full discussion of the possible causes of this syndrome is beyond the scope of this paper. The fact that it can be observed in so many countries across several decades, however, suggests that there are common elements involved. Some aspects of increasing globalization may be at work here. It may also be the case that the political power of older generations has increased. The two of these may even have interacted with labor market liberalizations in response to globalization differentially hurting the young. Neither the effects of globalization nor the political power of older generations is likely to diminish in the near-term future.

Governments can act to help alleviate young adult failure to thrive syndrome. The most important thing that they can do is to encourage the production of well-paying jobs for young people. They can do this in a number of ways. First, they could provide financing for small start-up companies. These companies are likely to harness the entrepreneurial spirit of the young. Governments can make starting these companies easier, by reducing needless regulations. Many markets are international now. Capital mobility is now so great that capital can easily be made productive all over the world. Governments can help young people take advantage of new international opportunities by providing support for international training programs and programs for making international business contacts. One the biggest challenges that governments in more developed countries 
face is how to finance the increasing retirement and healthcare costs of the elderly. Reforms which share this burden more equitably, rather than loading it mainly on the young, would also help reduce the spread of young adult failure to thrive syndrome.

Many developed countries are now spending large amounts of money in order to stimulate couples to have more children. Studies suggest that these efforts, thus far, have had some, although not much, effect (Gauthier 2007; Grant et al. 2004). The policies are usually designed to lower the cost of children to couples. But to the extent that young adult failure to thrive syndrome makes it difficult to form a partnership with enough financial resources and stability to support childbearing, then it is not surprising that the policies have had only modest success. Recognition of young adult failure to thrive syndrome suggests that certain reforms such as enabling young adults to easily enter and remain in the labor market (Bovenberg 2008) could have positive effects on fertility. Also institutional changes that allow for more efficient schooling and an earlier graduation without lowering human capital levels can extend the length of the working life and provide more opportunities for childbearing (Lutz and Skirbekk 2005).

While our attention has been focused on what appears to be critical matters with respect to increasing labor market flexibility and with respect to making pension and healthcare systems sustainable, policy-makers have generally been ignoring another equally important problem, the economic well-being of the young. If governments try to solve their labor market and fiscal problems at the expense of the young, they might find that they cannot solve them at all. True solutions to the economic problems associated with globalization and aging must take into account the well-being of all members of society, not just the old.

\section{References}

Andersson, G. 2000. The impact of labour-force participation on childbearing behaviour: Pro-cyclical fertility in Sweden during the 1980s and the 1990s. European Journal of Population 16(4): 293-333.

Arulampalam, W., A.L. Booth, and M.P. Taylor. 2000. Unemployment persistence. Oxford Economic Papers 52(1): 24-50.

Beaudry, P. and D. Green. 2000. Cohort patterns in Canadian earnings: assessing the role of skill premia in inequality trends. Canadian Journal of Economics. 33(4): 907-936.

Bell, L., G. Burtless, J. Gornick, and T.M. Smeeding. 2007. Failure to launch: Crossnational trends in the transition to economic independence. Pages 27-55 in S. Danzinger and C.E. Rouse (eds.), The Price of Independence: The Economics of Early Adulthood. New York: Russell Sage Foundation.

Bovenberg, A.L. 2008. The life-course perspective and social policies: An overview of the issues. CESifo Economic Studies 54(4): 593-641.

Clark, A.E. and A.J. Oswald. 1996. Satisfaction and comparison income. Journal of Public Economics 61: 359-381. 
Daly, M.C., D.J. Wilson, and N. Johnson. 2010. Relative Status and Well-Being: Evidence from U.S. Suicide Deaths. Working Paper No. 2007-12. San Francisco: Federal Reserve Bank of San Francisco.

Danzinger, S. and D. Ratner. 2010. Labor market outcomes and the transition to adulthood. The Future of Children 20(1): 133-158.

Easterlin, R.A. 1966. On the relation of economic factors to recent and projected fertility changes. Demography 3(1): 131-151.

Easterlin, R.A. 1980. Birth and Fortune: The Impact of Numbers on Personal Welfare. New York: Basic Books.

Eibner, C. and W.N. Evers. 2005. Relative deprivation, poor health habits, and mortality. Journal of Human Resources XL(3): 591-620.

Elstad, J.I., E. Dahl, and D. Hofoss. 2006. Associations between relative income and mortality in Norway: A register based study. European Journal of Public Health 16(6): 640-646.

EU. 2009. Employment situation and social outlook. Monthly Monitor, September. Brussels: European Union.

Farber, H.S. 2007. Is the company man an anachronism? Trends in long-term employment in the United States, 1973 to 2006. Pages 56-83 in S. Danzinger and C. Rouse (eds.), The Price of Independence: The Economics of Early Adulthood. New York: Russell Sage Foundation.

Gauthier, A.H. 2007. The impact of family policies on fertility in industrialized countries: A review of the literature. Population Research and Policy Review 26(3): 323-346.

Genda, Y. 2006. A Nagging Sense of Job Insecurity: The New Reality Facing Japanese Youth. Tokyo: I House Press.

Grant, J., S. Hoorens, S. Sivadasan, M. van het Loo, J. DaVanzo, L. Hale, S. Gibson, and W. Butz. 2004. Low Fertility and Population Aging. Causes, Consequences, and Policy Options. Santa Monica, USA: Rand Corporation.

Gregg, P. and E. Tominey. 2005. The wage scar from male youth unemployment. Labour Economics 12(4): 487-509.

Grund, C. and D. Sliwka. 2003. The Impact of Wage Increases on Job Satisfaction: Empirical Evidence and Theoretical Implications. IZA Discussion Paper No. 387. Bonn, Germany: IZA Institute for the Study of Labor.

Guardian. 2008. After the Baby Boomers Meet the 'Baby Losers'. Downloadable at: http://www.guardian.co.uk/world/2008/may/11/spain.france

Hacker, J., G. Huber, P. Rehm, M. Schlesinger, and R. Valletta. 2010. Economic Security at Risk. New York: The Rockefeller Foundation. Available from: http://www. economicsecurityindex.org/upload/media/Economic_Security_Index_Full Report.pdf

Hacker, J. 2008. The Great Risk Shift: The New Economic Insecurity and the Decline of the American Dream. New York: Oxford University Press.

Haffner, M. 2004. Housing Wealth of the Dutch Elderly: Savings for Old Age? Available from: www.urbancentre.utoronto.ca/pdfs/housingconference/Haffner Housing Wealth.pdf

Hommerich, C. 2009. 'Freeter' und 'Generation Praktikum' - Arbeitwerte in Wandel? Ein deutschen-japanischer Vergeich. Monograph of the German Institute of Japanese Studies No. 45. Munich: Ludicium. 
Incorvaia, A. and A. Rimassa. 2006. Generazione Mille Euro. Available from: http:// www.generazione $1000 . \mathrm{com} / \mathrm{index} 2 . \mathrm{htm}$

Japanese National Survey on Work and Family. 2007. Collected by Mainichi newspapers, Tokyo. Available from: scholarspace.manoa.hawaii.edu/bitstream/10125/3005/1/ c8160-1.pdf

Jappelli, T. and L. Pistaferri. 2000. The dynamics of household wealth accumulation in Italy. Fiscal Studies 21(2): 269-295.

Klevmarken, A. 2006. The Distribution of Wealth in Sweden: Trends and Driving factors. Working Paper No. 4. Uppsala, Sweden: Uppsala University, Economics Department.

Koytcheva, E. and D. Philipov. 2008. Bulgaria: Ethnic differentials in rapidly declining fertility. Demographic Research 19: 361-402. Available from: www.demographicresearch.org/Volumes/Vol19/13

Kravdal, Ø. 1999. Does marriage require a stronger economic underpinning than informal cohabitation? Population Studies 53: 63-80.

LIS. 2010. Luxembourg Income Study Database. Luxembourg Income Study. www. lisproject.org (last accessed: 06.2010)

Liu, G. and A.Vikat. 2004. Does Divorce Risk Depend on Spouses Relative Income: A Register-Based Study of First Marriages in Sweden in 1981-1998. MPIDR Working Paper 2004-10. Rostock, Germany: Max Planck Institute for Demographic Research.

Lutz, W. and V. Skirbekk. 2005. Policies addressing the tempo effect in low-fertility countries. Population and Development Review 31(4): 699-720.

Macunovich, D.J. 1998. Race and Relative Income/Price of Time Effects on U.S. Fertility. Journal of Socio-Economics 27(3): 365-400.

Macunovich, D.J. 2011a. Relative Cohort Size, Relative Income, and Women's Labor Force Participation, 1968-2010. IZA Discussion Paper, No. 5913.

Macunovich, D.J. 2011b. Re-Visiting the Easterlin Hypothesis: Marriage in the U.S. 1968-2010. IZA Discussion Paper, No. 5886.

Macunovich, D.J. 2011c. Re-Visiting the Easterlin Hypothesis: U.S Fertility. 19682010. IZA Discussion Paper, No. 5885.

Mills, M, H-P. Blossfeld, and E. Klijzing. 2005. Becoming an adult in uncertain times: A 14 country comparison of the losers of globalization. Pages 438-459 in H-P. Blossfeld, E. Klizing, M. Mills, and K. Kurz (eds.), Globalization, Uncertainty, and Youth in Society. London: Routledge.

Moffitt, R. and P. Gottschalk. 2002. Trends in the transitory structure of earnings. The Economic Journal C68-C73.

Morissette, R., G. Picot, and Y. Lu. 2013. The Evoluation of Canadian Wages Over the Last Three Decades. Statistics Canada. Social Analysis Branch. Analytial Studies Branch Research Paper Series.

Newsweek. 2007. The Lost Youth of Europe. Available from: http://www.newsweek. com/2007/03/11/the-lost-youth-of-europe.html

New York Times. 2006. Italy (sh!) Has a Problem. Available from: http://www.nytimes. com/2006/03/29/world/europe/29iht-italy.html

NRK. 2008. Kvinner vil at mannen skal tjene mest [Women want the man to earn 
most]. Available from: http://www.nrk.no/nyheter/okonomi/1.4879831

OECD. 2010. Employment Statistics. Available from: http://stats.oecd.org

OECD. 2008. Growing Unequal. Income Distribution and Poverty in OECD Countries. Paris: Organisation for Economic Co-operation and Development.

OECD. 2007. OECD Employment and Labour Market Statistics. Paris: Organisation for Economic Co-operation and Development.

Oswald, A. 1987. Efficient Contracts Are on the Labour Demand Curve: Theory and Facts. Discussion Paper No. 284. London: London School of Economics, Centre for Labour Economics.

Reinhart, C.M. and K.S Rogoff. 2008. Is the 2007 U.S. sub-prime financial crisis so different? An international comparison. American Economic Review 98: 339-344.

Stevenson, B. and J. Wolfers. 2009. The paradox of declining female happiness. American Journal of Economic Policy 1(2): 190-225.

U.S. Census Bureau. 2008. Poverty Rates by Age: 1959 to 2007. Current Population Survey, 1960 to 2008. Annual Social and Economic Supplements.

Van Bavel, J. 2010. Choice of study discipline and the postponement of motherhood in Europe. The impact of expected earnings, gender composition and family attitudes. Demography 47(2): 439-458.

Verick, S. 2009. Who is hit hardest during a financial crisis? The vulnerability of young men and women to unemployment in an economic downturn. IZA Discussion Paper 4359. Bonn, Germany: IZA Institute for the Study of Labor.

Vogel, J. and G. Råbäck. 2004. Materiell ojämlikhet i tids- och internationellt perspektiv [Material inequality over time and across countries]. Levnadsförhållanden Report 100, Chapter 4. Stockholm: Statistics Sweden.

Sanderson WC, V. Skribekk and M. Stonawski. 2011. Young adult failure to thrive syndrome. IIASA Interim Report IR-11-003.

Watson, T. and S. McLanahan. 2009. Marriage Meets the Joneses: Relative Income, Identity, and Marital Status. NBER Working Paper 14773. Cambridge, USA: National Bureau of Economic Research. http://www.nber.org/papers/w14773

WHO. 2010. WHO Mortality Database. Geneva, Switzerland: World Health Organization, Department of Health Statistics and Informatics. Available from: http://www.who.int/healthinfo/morttables/en/index.html 